\title{
Arsenic, Cadmium, and Thallium Content in the Plants Growing in Close Proximity to a Zinc Works - Long-Term Observations
}

\author{
Alicja Kicińska ${ }^{1}$ \\ 1 AGH University of Science and Technology, Faculty of Geology, Geophysics and Environmental Protection, \\ Department of Environmental Protection, Mickiewicza 30 av., 30-059 Kraków, Poland \\ e-mail: kicinska@geol.agh.edu.pl
}

\begin{abstract}
The paper comprises an analysis of the As, Cd, and Tl content in two plant species (Agrostis capillaris and Betula pendula) commonly growing in the vicinity of the Miasteczko Śląskie Zinc Works, in the period of 1998-2018. In 2018, the As, Cd, and $\mathrm{Tl}$ content (in $\mathrm{mg} / \mathrm{kg}$ ) in the grasses was 1.10-1.68, 3.14-19.05, and 0.53-5.96, respectively, i.e. lower by $50-70 \%$, compared to the year 1998 . The $\mathrm{As}, \mathrm{Cd}$, and $\mathrm{Tl}$ content (in $\mathrm{mg} / \mathrm{kg}$ ) in birch leaves at the same time point was $0.74-1.54,4.65-32.44$, and $0.80-7.57$, respectively, i.e. lower by $10-80 \%$, compared to values found 20 years earlier. In all grass and birch leaf samples collected in 1998 and 2018, the content of the studied elements exceeded the so-called "natural levels". The 1998 content of As, $\mathrm{Cd}$, and $\mathrm{Tl}$ in the plants was due to the settling of dust containing industrial pollutants and reached 77-96\%. After 20 years, the contribution of this source of pollution was considerably lower, reaching $63-79 \%$. The performed analyses demonstrated the following mean contents of the analyzed elements in dust: $243 \mathrm{mg} \mathrm{As} / \mathrm{kg}, 1113 \mathrm{mg} \mathrm{Cd} / \mathrm{kg}$, and $44 \mathrm{mg} \mathrm{Tl} / \mathrm{kg}$, which confirms the hypothesis on the major role of dust in the current soil and plant pollution. In all the habitats analyzed, a significant decrease of the transfer factor (TF) was found for As and Cd in 2018, compared to 1998. For Tl, a different observation was made. In three out of four analyzed habitats, $T F$ decreased over the two decades studied, whereas in the remaining habitat, $T F$ was higher in 2018 than in 1998 both for the grasses and for the birch leaves. Over the past 20 years, the most polluted area changed as well, from the land located closest to the zinc works, in the direction aligned with the most common winds, to the areas subject to the most intense settling of pollutants carried by the wind from unsecured heaps and industrial waste storage areas.
\end{abstract}

Keywords: potential toxic elements, Agrostis capillaris, Betula pendula, zinc works.

\section{INTRODUCTION}

Plants have two main sources of minerals. One is the lithosphere, or more precisely, its outermost layer called the pedosphere, from which plants absorb the macro- and micro-elements necessary for normal development through their root systems. The other potential source is precipitation or atmospheric dust settling on the aboveground parts of the plants, followed by a migration of solid or soluble pollutant particles through the stomata, resulting in their inclusion in the cellular metabolic processes (Chojnacka et al. 2005, Kicińska 2018, 2019). Beside the primary (O, C, $\mathrm{H}, \mathrm{N})$ and secondary nutrients $(\mathrm{Ca}, \mathrm{K}, \mathrm{Na}, \mathrm{S}, \mathrm{Mg}$, $\mathrm{P}$, and $\mathrm{Cl}$ ), plants also absorb trace elements, such as As, $\mathrm{Cd}$, or $\mathrm{Tl}$ (Tyler and Olsson 2001). The role of the latter in the life processes of plants has not yet been fully understood, but their occurrence is affected by a number of factors, including cation exchange through cellular membranes, intracellular transport, as well as the processes occurring in the rhizosphere, which are also associated with the presence and activity of microorganisms (Kabata-Pendias and Pendias 1999, Kicińska and Mamak 2011, Kicińska et al. 2019). The movement of trace elements, including heavy metals such as $\mathrm{Cd}, \mathrm{Zn}, \mathrm{Cr}$, or $\mathrm{Hg}$, into various plant organs may have a number of adverse consequences, including inhibition of growth, decrease of dry weight yield, or metabolic dysfunction within the photosynthesis process (De Miguel et al. 2016, Ernst 2006, Kicińska 2016, Liu et al. 2016, SzarekŁukaszewska 2009). The adverse effects of the 
metals may also be seen in the rhizosphere itself, including alterations to root morphology (thickening or thinning, curvature etc.) or inhibition of root growth.

When growing in an environment with heavy long-term pollution, many plant species develop the mechanisms that increase their tolerance to xenobiotics, which not only allows them to survive, but also to reproduce, with no symptoms of toxicity (Larcher 2003, Pulford and Watson 2003, Turan et al. 2011). The adaptive mechanisms for developing tolerance to high concentrations of pollutants vary greatly, depending mainly on plant species, but also on the chemical and physical properties of the pollutant and its derivatives (Maskall et al. 1996, Newman and Jagoe 1996). Due to the above-mentioned considerations, the study material comprising the above-ground parts of two common plant species was collected in the vicinity of a zinc works. Then: $(i)$ total contents of particularly toxic elements, i.e. As, $\mathrm{Cd}$, and $\mathrm{Tl}$, were determined in the plant samples; (ii) the pollutant levels were compared with those found in the same material 20 years earlier; (iii) an attempt was made to identify the primary source of these pollutants based on the spatial distribution analysis; (iv) transfer factor $(T F)$ was calculated to evaluate the condition of the studied environment at the two time points.

\section{STUDY AREA}

The Miasteczko Śląskie Zinc Works is located in southern Poland, in the Silesia Province, in the town of Miasteczko Śląskie. The area is part of the Upper Silesian Depression, which features Triassic deposits containing $\mathrm{Zn}-\mathrm{Pb}$ ores. It is covered with Pleistocene moraine clay reaching up to $10 \mathrm{~m}$ in thickness, with localized exposures of loesses. The bedrock is comprised of Triassic sandstone, with Jurassic limestone outcrops.

The main types of soils include podsols, pseudo-podsols (developing from sands) and weakly loamy soils, as well as brown earth soils; poorly formed rendzina soils are also found locally. Agricultural land accounts for $29.9 \%$, and arable land - for $23.6 \%$ of the total area. In Miasteczko Śląskie, most soils $(60.3 \%)$ belong to land use classes $\mathrm{IV}_{\mathrm{B}}$ and V, while class I, II, and III ${ }_{\mathrm{A}}$ soils are not found.

Predominant winds in the area are west and north-west, accounting for $35.5 \%$ of annual winds. Annual precipitation total is $640 \mathrm{~mm}$, and the highest precipitation occurs in May.

The Miasteczko Śląskie Zinc Works annually produces $60,000 \mathrm{t}$ of refined $\mathrm{Zn}, 35,000 \mathrm{t}$ of $\mathrm{Pb}$, and $100,000 \mathrm{t}$ of sulfuric acid. The production technology comprises two processes: processing of $\mathrm{Zn}$ and $\mathrm{Pb}$ concentrates from sulfide ores, and processing of carbonate-hosted $\mathrm{Zn}$ and $\mathrm{Pb}$ ores (Kicki 1997). This is the only plant in Poland and one of eight in the world producing $\mathrm{Zn}$ and $\mathrm{Pb}$ using the Imperial Smelting Process (ISP). The process is highly efficient and allows for processing complex polymetallic raw materials that may not be processed by other methods. The feed mixture in the ISP process includes primary materials (mainly $\mathrm{Zn}-\mathrm{Pb}$ concentrates and $\mathrm{Zn}$ oxide) and secondary, recycled materials containing $\mathrm{Zn}$ and $\mathrm{Pb}$ (Kosa-Burda and Kicińska 2016, Nowińska 2003).

\section{MATERIAL AND METHODS}

The primary research material included the above-ground parts of plants belonging to the Agrostis capillaris grass species and the Betula pendula birch species. These species were selected due to their high resistance and tolerance to high metal levels in the environment. The study by Czerniak and Poszyler-Adamska (2006) demonstrated that the assimilation system of Betula pendula has a tendency for dioxin accumulation. Therefore, the species is commonly considered a good indicator of pollutant accumulation (Kayzer et al. 2011).

Additionally, in 2018, a dust sample was collected from the surface of the ground (at site no. 1, Fig. 1), which comprised approx. $0.5 \mathrm{~kg}$ of dust with a grain size below $0.01 \mathrm{~mm}$.

The plant samples were collected in late September 2018, from the same 4 habitats that were used in the study conducted in 1998 (Fig. 1, 1-4). This allowed for performing a long-term (20-year) analysis of changes in the chemical composition of plants growing in the area. The selected habitats differed in terms of distance and direction from the main sources of pollutant emissions, i.e. the zinc works, the waste storage area, and the main transport routes. The material collected from each habitat included 30 specimens (above-ground parts) of Agrostis capillaris grass and approx. $0.5 \mathrm{~kg}$ of leaves from the sameaged specimens of Betula pendula birch. All plant samples were rinsed 3 times with $300 \mathrm{ml}$ of 
distilled water, and subsequently dried, ground, and homogenized.

The plant tissues were then digested in a microwave furnace (HPR 1000/10s high pressure segmented rotor at $200^{\circ} \mathrm{C}$, microwave power up to $1000 \mathrm{~W}$ ) in accordance with digestion application no. DG-AG-02, using $10 \mathrm{ml}$ of $65 \% \mathrm{HNO}_{3}$ and a double dose of $5 \mathrm{ml} 30 \% \mathrm{H}_{2} \mathrm{O}_{2}$. The weighed amount of plant material for analysis was $1 \mathrm{~g}$ per sample.

The dust sample was analyzed by extraction in a mixture of concentrated acids $\left(\mathrm{HCl}+\mathrm{HNO}_{3}\right.$ at a $3: 1$ ratio) at a temperature of $130^{\circ} \mathrm{C}$. The weighed amount was $1 \mathrm{~g}$.

In order to evaluate the amount of $\mathrm{As}, \mathrm{Cd}$, and $\mathrm{Tl}$ absorbed by plants growing in heavily polluted areas, the transfer factor $(T F)$ was calculated for each metal by dividing the amount of the element in the plant by its content in the soil where the plant had been growing (Chojnacka et al. 2005, Kicińska and Gruszecka-Kosowska 2016).

The As, Cd, and $\mathrm{Tl}$ levels in post-extraction solutions were determined using the Elan 6100 ICP-MS system, with a limit of quantification of $2 \cdot 10^{-5} \mathrm{mg} \cdot \mathrm{dm}^{-3}$. The statistical analyses were performed using the Statistica software, version 13.1.

\section{RESULTS AND DISCUSSION}

\section{As, Cd, and Tl content in Agrostis capillaris grass}

The grass samples collected in 2018 had the $\mathrm{As}, \mathrm{Cd}$, and $\mathrm{Tl}$ content in the following ranges (in $\mathrm{mg} / \mathrm{kg}$ ): 1.10-1.68, 3.14-19.05, and 0.53-5.96, respectively (Table 1 ). In comparison with the samples analyzed 20 years earlier, the quantities are lower by a mean of $70 \%$ (for As) and 50\% (for $\mathrm{Cd}$ and $\mathrm{Tl}$ ). However, in all the samples analyzed, the $\mathrm{As}, \mathrm{Cd}$, and $\mathrm{Tl}$ content exceeded the so-called natural levels for grasses, defined at: $0.33,0.6$, and $0.03 \mathrm{mg} / \mathrm{kg}$, respectively (Kabata-Pendias and Pendias 1999).

In 1998, the highest As and Cd levels were found in habitat no. 2, located nearest to the zinc works approx. $100 \mathrm{~m}$ to the south-east of it (Fig. 2). The highest $\mathrm{Tl}$ levels were found in the grass samples from habitat no. 3 , which was also in close proximity to the zinc works (approx. $100 \mathrm{~m}$ ), but to the south. As already mentioned, the analyzed element levels were considerably lower 20 years later, indicating a positive change, but at the same time, different habitats were found to be the most polluted. In 2018, the highest As content was found in the plant material from habitat no. 4. As to $\mathrm{Cd}$ and $\mathrm{Tl}$, the highest levels were found in the grass samples from habitat no. 1 (Fig. 2). Both of these sites lie north of the zinc works - habitat no. 1 is approx. $200 \mathrm{~m}$ to the east, while habitat no. 5 is even further away, approx. $500 \mathrm{~m}$ to the west (Fig. 1).

Compared to the present findings, extremely high As and Cd levels were reported by Bech et al. (2012) in the plants of the same species growing in NE Spain, Girona Province. In the plants growing around former antimony mine in the Ribes Valley, the As levels of up to $238 \mathrm{mg} / \mathrm{kg}$ and Cd levels of up to $0.6 \mathrm{mg} / \mathrm{kg}$ were found. In the Bukowno area in the south of Poland, where $\mathrm{Zn}-\mathrm{Pb}$ ores are mined and processed, slightly higher levels of As were reported, reaching $10-16 \mathrm{mg} / \mathrm{kg}$, while the levels of Cd were slightly lower, $5-37 \mathrm{mg} / \mathrm{kg}$ (Kicińska and Gruszecka-Kosowska 2016).

\section{As, Cd, and TI content in Betula pendula birch}

The birch leaf samples collected in 2018 had the $\mathrm{As}, \mathrm{Cd}$, and $\mathrm{Tl}$ content in the following ranges

Table 1. Content of As, $\mathrm{Cd}$ and $\mathrm{Tl}$ in grasses Agrostis capillaris from the close vicinity of the $\mathrm{Zn}$-smelter

\begin{tabular}{|c|c|c|c|c|c|c|}
\hline \multirow{2}{*}{ Parameters } & \multicolumn{2}{|c|}{ As } & \multicolumn{2}{|c|}{$\mathrm{Cd}$} & \multicolumn{2}{|c|}{$\mathrm{TI}$} \\
\hline & \multicolumn{6}{|c|}{$\left(\mathrm{mg} \cdot \mathrm{kg}^{-1}\right)$} \\
\hline Sample sites & 1998 & 2018 & 1998 & 2018 & 1998 & 2018 \\
\hline 1 & 3.50 & 1.10 & 5.70 & 19.05 & 3.70 & 5.96 \\
\hline 2 & 4.40 & 1.12 & 28.40 & 8.01 & 6.30 & 4.07 \\
\hline 3 & 4.10 & 1.14 & 22.20 & 3.52 & 7.40 & 0.53 \\
\hline 4 & 4.30 & 1.68 & 4.70 & 3.14 & 5.70 & 0.83 \\
\hline \multicolumn{7}{|l|}{ For all samples $(n=20)$} \\
\hline$A v \pm S D$ & $4.08 \pm 0.35$ & $1.26 \pm 0.24$ & $15.25 \pm 5.29$ & $8.43 \pm 3.21$ & $5.78 \pm 1.34$ & $2.85 \pm 2.13$ \\
\hline $\mathrm{Me}$ & 4.20 & 1.13 & 13.95 & 5.76 & 6.00 & 2.45 \\
\hline $\begin{array}{l}\text { Natural content }{ }^{\mathrm{b}} \\
\text { (\% of samples upper this limit) }\end{array}$ & \multicolumn{2}{|c|}{$\begin{array}{c}0.28-0.33 \\
(100 \%)\end{array}$} & \multicolumn{2}{|c|}{$\begin{array}{c}0.05-0.6 \\
(100 \%) \\
\end{array}$} & \multicolumn{2}{|c|}{$\begin{array}{c}0.02-0.03 \\
(100 \%) \\
\end{array}$} \\
\hline
\end{tabular}

${ }^{a}$ For 1998 (Kicińska-Świderska 1999); ${ }^{\text {b }}$ According to Kabata-Pendias and Pendias (1999). 


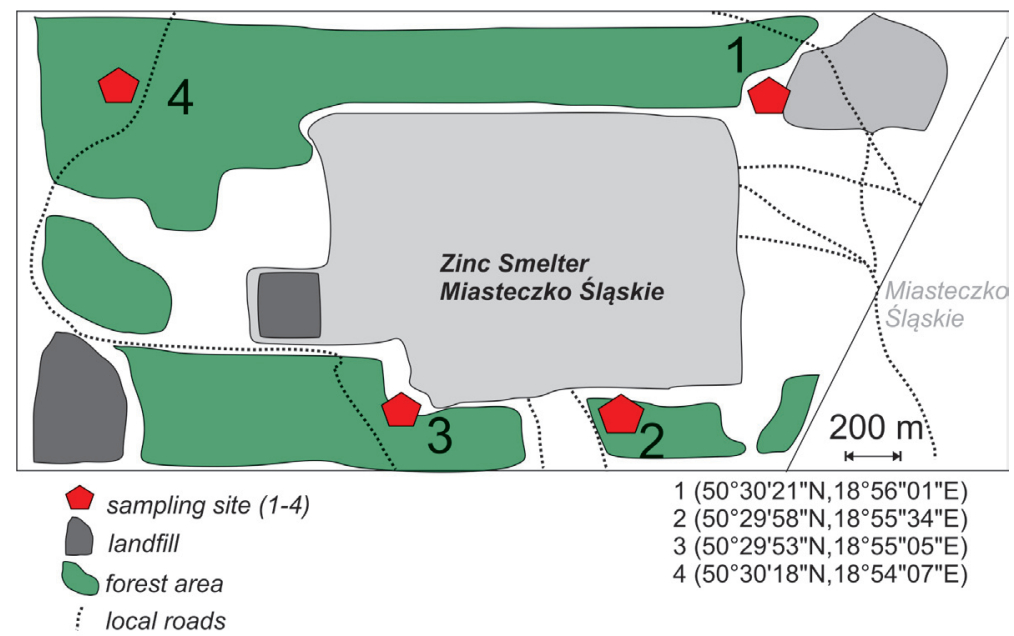

Figure 1. Sampling sites
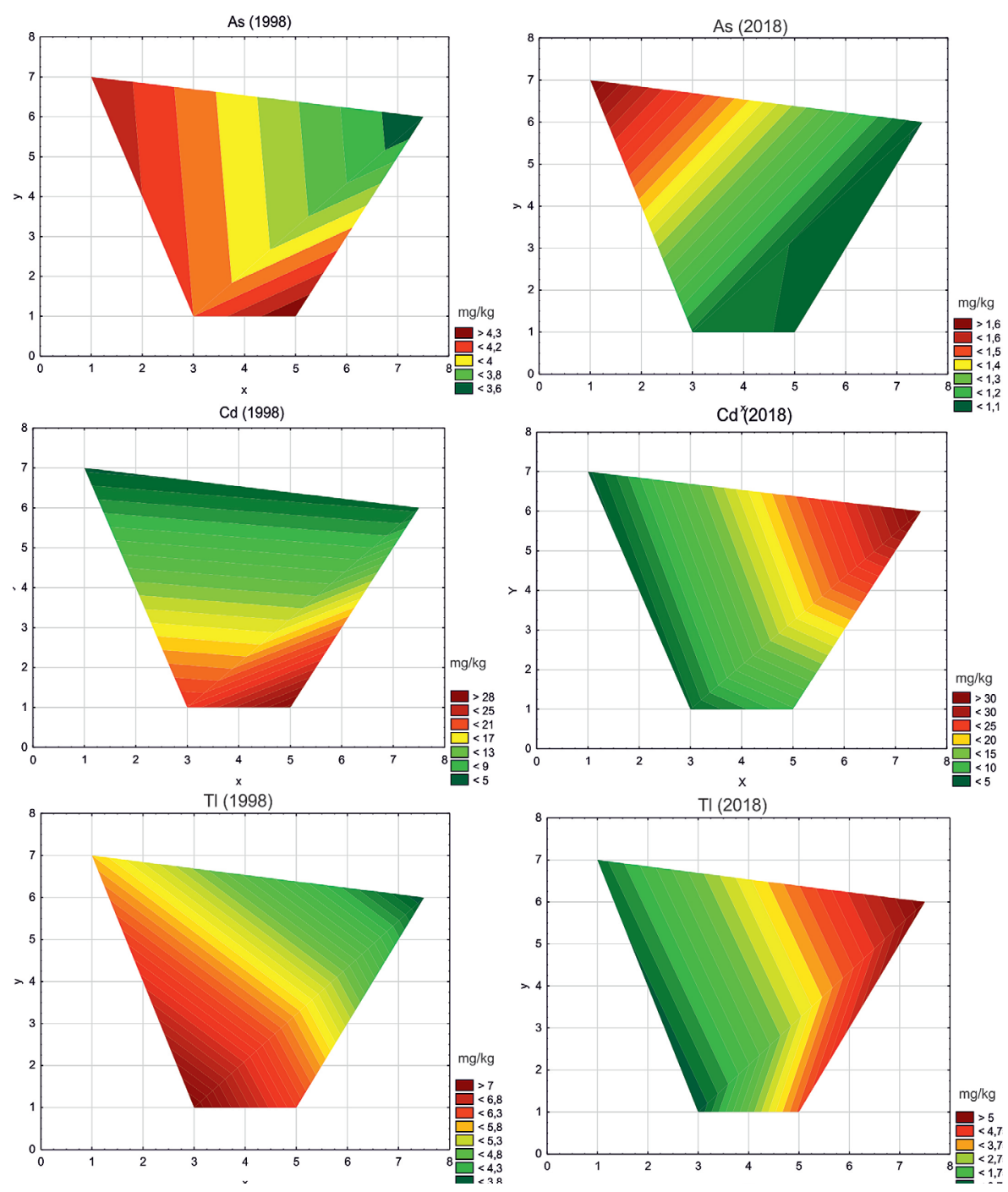

Figure 2. Spatial distribution of $\mathrm{As}, \mathrm{Cd}$ and $\mathrm{Tl}$ content in Agrostis capillaris

(in mg/kg): 0.74-1.54, 4.65-32.44, and 0.80-7.57, respectively (Table 2 ). Compared to the amounts found 20 years earlier, these levels are lower by a mean of $80 \%$ (for $\mathrm{As}$ ), $10 \%$ (for $\mathrm{Cd}$ ) and $60 \%$ (for
$\mathrm{Tl})$. Despite such a considerable decrease in the levels of these elements, the natural levels were still exceeded in all birch leaf samples - similarly to the findings in grass samples. 
Table 2. Content of As, $\mathrm{Cd}$ and $\mathrm{Tl}$ in birch leaves Betula pendula from the close vicinity of the $\mathrm{Zn}$-smelter

\begin{tabular}{|c|c|c|c|c|c|c|}
\hline \multirow{2}{*}{ Parameters } & \multicolumn{2}{|c|}{ As } & \multicolumn{2}{|c|}{$\mathrm{Cd}$} & \multicolumn{2}{|c|}{$\mathrm{TI}$} \\
\hline & \multicolumn{6}{|c|}{$\left(\mathrm{mg} \cdot \mathrm{kg}^{-1}\right)$} \\
\hline Sample sites & $1998^{a}$ & 2018 & 1998 & 2018 & 1998 & 2018 \\
\hline 1 & 6.30 & 1.54 & 11.00 & 32.44 & 7.90 & 1.95 \\
\hline 2 & 8.50 & 0.74 & 30.20 & 9.85 & 9.80 & 1.97 \\
\hline 3 & 5.70 & 1.39 & 8.20 & 5.76 & 8.30 & 0.80 \\
\hline 4 & 4.90 & 0.98 & 8.00 & 4.65 & 7.70 & 7.57 \\
\hline \multicolumn{7}{|l|}{ For all samples $(n=20)$} \\
\hline$A v \pm S D$ & $6.35 \pm 0.82$ & $1.16 \pm 0.16$ & $14.35 \pm 4.51$ & $13.18 \pm 5.61$ & $8.43 \pm 0.41$ & $3.07 \pm 1.32$ \\
\hline $\mathrm{Me}$ & 6.00 & 1.18 & 9.60 & 7.80 & 8.10 & 1.96 \\
\hline $\begin{array}{l}\text { Natural content }{ }^{\mathrm{b}} \\
\text { (\% of samples upper this limit) }\end{array}$ & \multicolumn{2}{|c|}{$\begin{array}{c}0.28-0.33 \\
(100 \%)\end{array}$} & \multicolumn{2}{|c|}{$\begin{array}{l}0.05-0.6 \\
(100 \%)\end{array}$} & \multicolumn{2}{|c|}{$\begin{array}{c}0.02-0.03 \\
(100 \%)\end{array}$} \\
\hline
\end{tabular}

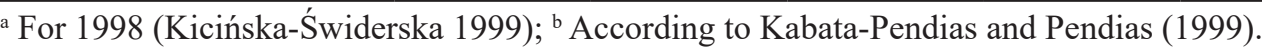

Compared to the present findings, slightly lower As and Cd levels were found in 2014 by Kicińska and Gruszecka-Kosowska (2016) in the leaves from birches growing in the Bukowno area. The authors found the As content of $0.7 \mathrm{mg} / \mathrm{kg}$, and a Cd content of $3.1 \mathrm{mg} / \mathrm{kg}$.

An analysis of the spatial distribution of the most and least polluted samples showed that in 1998, the contamination was the highest in habitat no. 2. After two decades, the highest As and $\mathrm{Cd}$ levels were found in birch leaves from habitat no. 1, and the highest $\mathrm{Tl}$ levels in the samples from habitat no. 4 - as in the case of grass samples (Fig. 3).

\section{Source(s) of As, Cd, and TI}

Next, the associations between the studied elements were analyzed. For this purpose, the correlation coefficients were calculated for both species and both sample series (Table 3). Weak or no correlations were found for the $\mathrm{Cd}-\mathrm{Tl}$ and $\mathrm{As}-\mathrm{Tl}$ content in the birch leaves collected in 2018. No correlations for $\mathrm{As}-\mathrm{Cd}$ or $\mathrm{As}-\mathrm{Tl}$ were found i the grass samples from the same series. Strong correlations were found for the As and Cd levels in the grass samples from 1998, and in the birch leaf samples from 2018. Very strong correlations $\left(r^{2}<0.7\right)$ were found for the As-Tl and Cd-Tl levels in the grass samples collected in 1998. Nearly complete correlations $\left(r^{2}<0.9\right)$ were found for the Cd-Tl levels in the grass samples from 2018 and all analyzed element pairs in the birch leaf samples from 1998. This indicates the existence of a common source of the analyzed elements, both in 1998 and in 2018.

Cluster analysis performed on the datasets for the 1998 grass and birch leaf samples demonstrated that the primary source of plant pollution was likely the settling of industrial dust containing vast quantities of the trace elements (Fig. 4). The samples from the sites nearest to the zinc works and located along the main line of dust settling were the most polluted.

In the material collected in 2018, the dendrogram has a different distribution (Fig. 4). The samples from habitats 3 and 4 have the highest values, while habitat no. 1 is a clear outlier. This is due to a change of the main reason of the pollution - currently, it involves the poorly secured waste storage areas and old slag heaps, subject to intense weathering processes, mainly due to atmospheric factors. The processes seen in the area include aeolian transport of fine particles as well as suffosion of toxic elements by precipitation water.

Principal component analysis (PCA) for the collected data demonstrated that in 1998, the As, $\mathrm{Cd}$, and $\mathrm{Tl}$ content in birch leaves was in $96 \%$ due to the settling of dust containing large quantities of trace metals, including those analyzed in the present study. After 20 years, the contribution of this source was considerably lower, amounting to $63 \%$ in 2018 . For grasses, in $1998,77 \%$ of the entire pollutant load on the plants was delivered through the atmosphere, while 20 years later, the share was $79 \%$.

The difference in the share of pollutants deposited on the plants through the atmosphere is due to two fundamental reasons: one, the different plant height, and two, the different morphology of their above-ground parts.

\section{As, Cd, and Tl in dust}

The raw material processing performed at the Miasteczko Śląskie zinc works does not only involve materials such as zinc-lead concentrates 

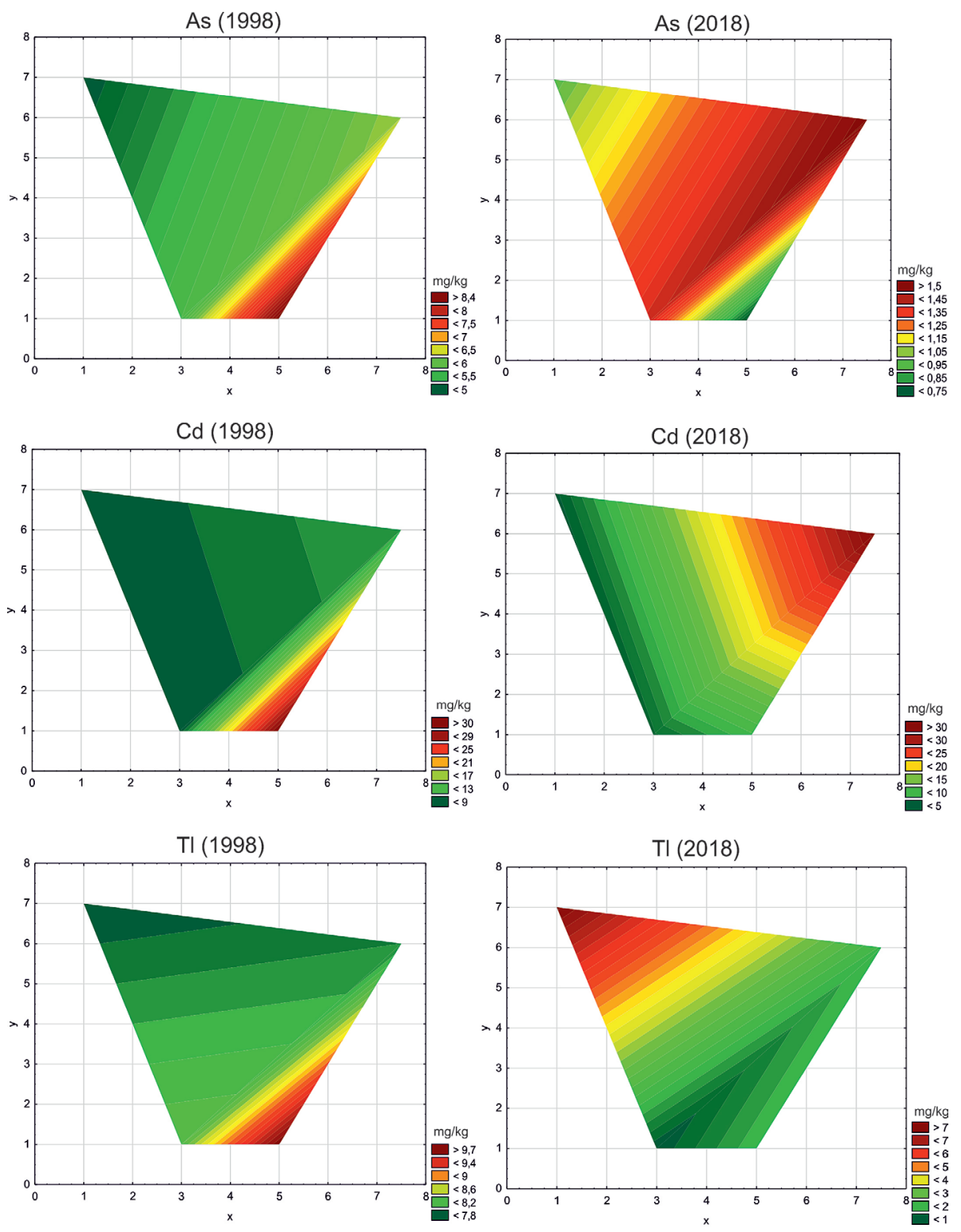

Figure 3. Spatial distribution of $\mathrm{As}, \mathrm{Cd}$ and $\mathrm{Tl}$ content in Betula pendula

Table 3. Correlation coefficient for As, $\mathrm{Cd}$ and $\mathrm{Tl}$ concentrations in Agrostis capillaris and Betula pendula (for $\mathrm{p}<0.05)$

\begin{tabular}{|c|c|c|c|c|c|c|}
\hline \multicolumn{4}{|c|}{ Agrostis capillaris (1998) } & \multicolumn{3}{c|}{ Agrostis capillaris (2018) } \\
\hline & As & Cd & TI & As & Cd & TI \\
\hline As & 1.00 & - & - & 1.00 & - & - \\
\hline Cd & 0.53 & 1.00 & - & -0.54 & 1.00 & 1.00 \\
\hline $\mathrm{TI}$ & 0.74 & 0.70 & 1.00 & -0.57 & 0.93 & TI \\
\hline \multicolumn{7}{|c|}{ Betula pendula (1998) } \\
\hline
\end{tabular}

or raw zinc oxide. The feed material for the furnaces also includes secondary materials, such as recycled zinc-lead materials, sludges, smelting residues, or dusts. Beside the main constituent elements, zinc and lead, these materials also contain other metals that may be a potential source of the elements analyzed in the present study. The research on the content and distribution of 

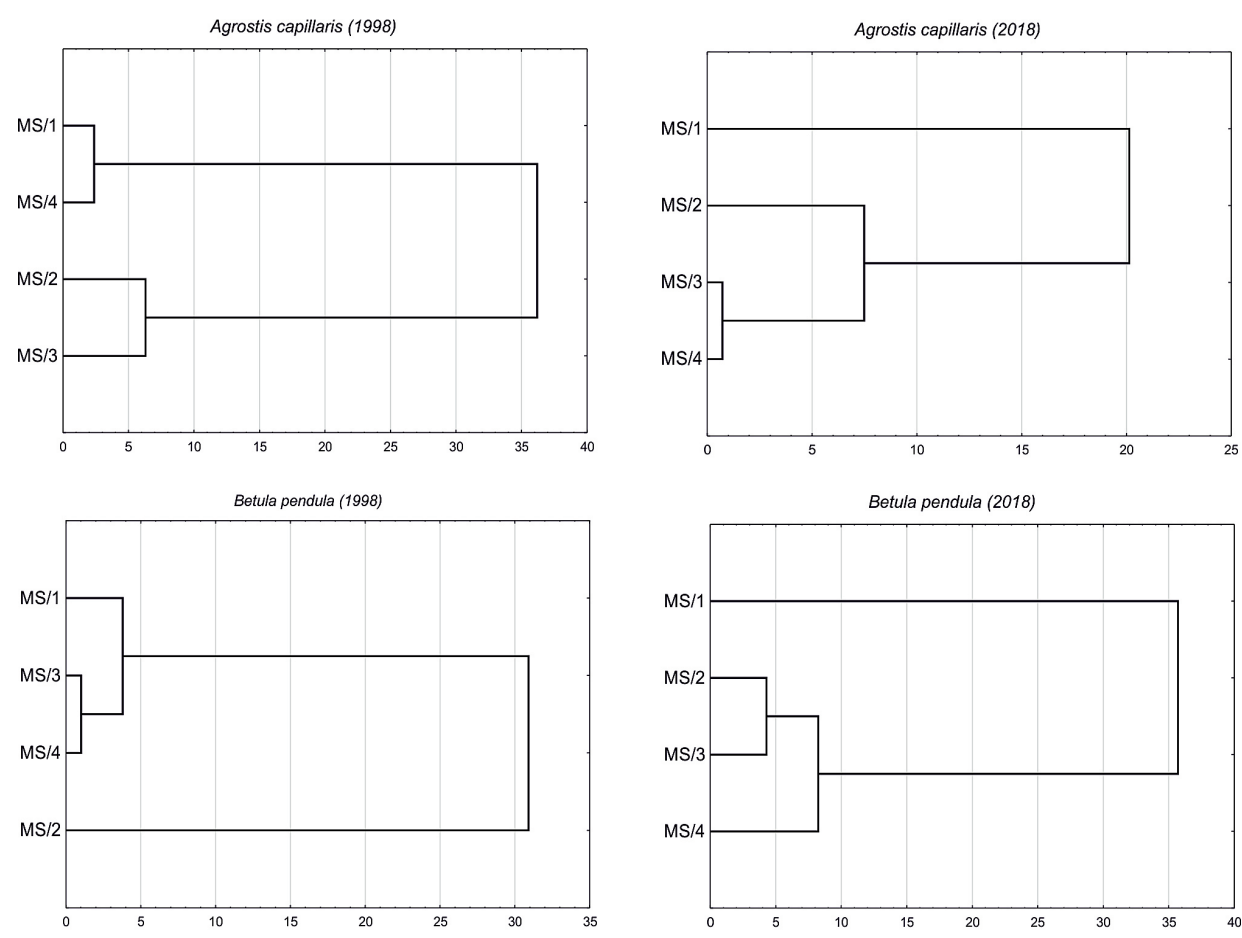

Figure 4. Transfer factor values for $\mathrm{As}, \mathrm{Cd}$ and $\mathrm{Tl}$ concentrations in Agrostis capillaris and Betula pendula

selected trace elements at all processing stages, from the $\mathrm{Zn}-\mathrm{Pb}$ concentrate to waste material, as exemplified by the Miasteczko Sląskie zinc works, was performed by Nowińska (2003), who found the As content of up to $0.19 \%$ and the $\mathrm{Cd}$ content of up to $0.8 \%$ in the dust from fabric filters and in smelting residues. The author reported that $\mathrm{Cd}$ was mainly present as an isomorphic impurity in zinc minerals, and accumulated in sulfate or oxide forms in cadmium-bearing dusts. Arsenic is found as an impurity in iron sulfates, in the form of toxic intermetallic compounds mainly $\mathrm{Zn}_{3} \mathrm{As}_{2}, \mathrm{FeAs}$, and $\mathrm{FeAs}_{2}$. Similarly to $\mathrm{Cd}$, As tends to accumulate in dust or slag. Thallium also accumulates to a considerable extent in cadmium-bearing dusts and in slag, and tends to bond to cadmium through ion exchange.

The As dust was clearly identified as the source of pollution, a dust sample from site no. 1 (Fig. 1) was tested for $\mathrm{As}, \mathrm{Cd}$, and $\mathrm{Tl}$ content. The following values were found (in $\mathrm{mg} / \mathrm{kg}$ ): 243,1113 , and 44 , respectively. These values significantly exceed the natural soil levels: $0.1-30$, $0.01-0.8$, and $0.01-2.8 \mathrm{mg} / \mathrm{kg}$, respectively (Kabata-Pendias and Szteke 2012), as well as the maximum allowed As and C levels for class IV lands set by the Regulation of the Minister for Environment (2016) on the evaluation of land surface contamination: 100 and $15 \mathrm{mg} / \mathrm{kg}$, respectively. Therefore, the present hypothesis on the major contribution of dust to the current pollution of soil and plants may be considered confirmed.

\section{Transfer factor for As, Cd, and TI}

On the basis of the As, $\mathrm{Cd}$, and $\mathrm{Tl}$ content found in plant and soil samples (reported in Kicińska 2019 - pending publication), which amounted to 250,454 , and $40 \mathrm{mg} / \mathrm{kg}$ (median content), respectively, the transfer factor $(T F)$ values were calculated (Table 4). In all the habitats analyzed, a significant decrease of $T F$ was found for As and Cd in 2018, compared with 1998. Mean 1998 $T F$ values for As were 0.128 (grass) and 0.187 (birch), while the $2018 T F$ values were 0.005 (grass) and 0.006 (birch). For $\mathrm{Cd}$, the $T F$ value for the grasses sampled in 1998 was 0.767 , while the 2018 value was 0.037 . The $T F$ value of $\mathrm{Cd}$ in birches also decreased in the analyzed period, from 0.473 to 0.057 . For Tl, a different observation was made. Overall, over the past 20 years, the $T F$ decreases were observed in three out of four habitats. Habitat no. 2 was an exception, as the TF values calculated there increased between 1998 and 2018, with regard to both grasses and birches.

In 1998, the highest $T F$ values were found for $\mathrm{Cd}$, both in grasses and birches. After 20 years, the highest $T F$ values in both species were found for $T 1$.

These findings indicate a lower uptake of the analyzed elements from the soil. 
Table 4. Dendrograms of As, $\mathrm{Cd}$ and $\mathrm{Tl}$ content in Agrostis capillaris and Betula pendula

\begin{tabular}{|c|c|c|c|c|c|c|}
\hline \multicolumn{5}{|c|}{ Agrostis capillaris (1998) } & \multicolumn{3}{c|}{ Agrostis capillaris (2018) } \\
\hline Site & As & Cd & TI & As & Cd & TI \\
\hline 1 & 0.103 & 0.238 & 0.154 & 0.004 & 0.026 & 0.081 \\
\hline 2 & 0.023 & 0.151 & 0.134 & 0.005 & 0.048 & 0.815 \\
\hline 3 & 0.315 & 2.467 & 0.435 & 0.010 & 0.075 & 0.105 \\
\hline 4 & 0.070 & 0.214 & 0.154 & 0.002 & 0.001 & 0.006 \\
\hline For all samples & 0.128 & 0.767 & 0.219 & 0.005 & 0.037 & 0.252 \\
\hline \multicolumn{7}{|c|}{ Betula pendula (1998) } \\
\hline Site & As & Cd & TI & As & Betula pendula (2018) & Cd \\
\hline 1 & 0.185 & 0.458 & 0.329 & 0.006 & 0.044 & 0.026 \\
\hline 2 & 0.044 & 0.161 & 0.209 & 0.003 & 0.059 & 0.393 \\
\hline 3 & 0.438 & 0.911 & 0.488 & 0.012 & 0.123 & 0.159 \\
\hline 4 & 0.080 & 0.364 & 0.208 & 0.001 & 0.002 & 0.053 \\
\hline For all samples & 0.187 & 0.473 & 0.309 & 0.006 & 0.057 & 0.158 \\
\hline
\end{tabular}

\section{CONCLUSION}

The findings from the sampling and physical and chemical analyses performed in 1998 and 2018 warrant drawing the following conclusions: 1. In Agrostis capillaris grass, the $\mathrm{As}, \mathrm{Cd}$, and $\mathrm{Tl}$ content in 2018 was lower by a mean of 50-70\%, compared with the values found in 1998. However, all the samples collected in 1998 and 2018 had a content of the analyzed elements that significantly exceeded the socalled natural levels.

2. In Betula pendula birch leaves, the levels of $\mathrm{As}, \mathrm{Cd}$, and $\mathrm{Tl}$ found in 2018 were lower by a mean of $10-80 \%$ than those found in 1998 . Still, all the samples collected in 1998 and 2018 exceeded the so-called natural levels of these elements.

3. The 1998 content of $\mathrm{As}, \mathrm{Cd}$, and $\mathrm{Tl}$ in the plants was due to the settling of dust containing industrial pollutants in as much as $96 \%$. After 20 years, the contribution of this source was considerably lower, amounting to $63 \%$ in 2018. For grasses, in $1998,77 \%$ of the entire pollutant load on the plants was delivered through the atmosphere, while 20 years later, the share was $79 \%$.

4. The total content of the analyzed elements in dust was: $243 \mathrm{mg} \mathrm{As} / \mathrm{kg}, 1113 \mathrm{mg} \mathrm{Cd} / \mathrm{kg}$, and $44 \mathrm{mg} \mathrm{Tl} / \mathrm{kg}$, which confirms the hypothesis on the major role of dust in the current soil and plant pollution.

5. Over the past 20 years, the location of the most polluted areas has changed, from the areas nearest to the zinc works and along the direction of the most common winds, to the sites subject to most intense settling of fine particles carried by wind from industrial waste storage yards or old, unsecured heaps.

The significant decrease of As, Cd, and Tl levels in the plant samples analyzed is a very desirable, optimistic finding, which demonstrates the efficiency of the measures implemented to limit the adverse impact of zinc works on its nearest surroundings. However, the change in the location of the most polluted areas in the studied 20-year period means that new measures must be employed to neutralize and reclaim the affected land.

\section{Acknowledgments}

The research was funded as part of statutory audits of the AGH KOŚ in Kraków, no. 16.16.140.315.

\section{REFERENCES}

1. Bech J., Corrales I., Tume P., Barceló J., Duran P., Roca N., Poschenrieder C. 2012. Accumulation of antimony and other potentially toxic elements in plants around a former antimony mine located in the Ribes Valley (Eastern Pyrenees). Journal of Geochemical Exploration 113: 100-105, doi:10.1016/j.gexplo.2011.06.006

2. Chojnacka K., Chojnacki A., Górecka H., Górecki H. 2005. Bioavailability of heavy metals form polluted soils to plants. Science of the total Environment 337, 175-182.

3. Czerniak A., Poszyler-Adamska A. 2006. Zawartość dioksyn i metali ciężkich $\mathrm{w}$ aparacie asymilacyjnym sosny zwyczajnej (Pinius sylvestris L.) i brzozy brodawkowatej (Betula pendula Roth.) rosnących w sąsiedztwie lokalnego składowiska 
odpadów. Zeszyty Problemowe Postępów Nauk Rolniczych, 515, PAN, p. 476-54.

4. De Miguel E., Izquierdo M., Gómez A., Mingot J., Barrio-Parra F. 2016. Risk assessment from exposure to arsenic, antimony, and selenium in urban gardens (Madrid, Spain). Environmental toxicology and chemistry, 36, 2: 544-550, doi.org/10.1002/ etc. 3569

5. Ernst W.H.O. 2006. Evolution of metal tolerance in higher plants, For. Snow Landsc. Res. 80, 3: 251-274

6. Kabata-Pendias A., Pendias H. 1999. Biogeochemia pierwiastków śladowych, PWN.

7. Kabata-Pendias A., Szteke B. 2012. Trace elements in geo- and biosphere, IUNG-PIB, Pulawy

8. Kayzer D., Czerniak A., Poszyler-Adamska A. 2011. Effect of trace elements on the morphometric parameters of assimilation apparatus in white birch. Infrastructure and Ecology of Rural Areas, 2, 261-273.

9. Kicińska A. 2019. Chemical and mineral composition of fly ashes from home furnaces, and health and environmental risk related to their presence in the environment. Chemosphere, vol. 215 (2019): 574-585, doi: https://doi.org/10.1016/j.chemosphere.2018.10.061

10. Kicińska A. 2016. Risk assessment of children's exposure to potentially harmful elements (PHE) in selected urban parks of the Silesian agglomeration. E3S Web of Conferences, Volume: 10 Article Number: UNSP 00035, DOI: 10.1051/e3sconf $/ 20161000035$

11. Kicińska A. 2018. Health risk assessment related to an effect of sample size fractions: methodological remarks. Stochastic Environmental Research and Risk Assessment, 32: 1867-1887, https://doi. org/10.1007/s00477-017-1496-7

12. Kicińska A., Mamak M., 2017. Health risks associated with municipal waste combustion on the example of Laskowa commune (Southern Poland). Human and Ecological Risk Assessment, vol.: 23(8): 2087-2096, doi: 10.1080/10807039.2017.1364131

13. Kicińska A., Gruszecka-Kosowska A. 2016. Longterm changes of metal contents in two metallophyte species (Olkusz area of $\mathrm{Zn}-\mathrm{Pb}$ ores, Poland). Environmental Monitoring and Assessment, 188: 6, DOI:10.1007/s10661-016-5330-3

14. Kicińska A., Smreczak B., Jadczyszyn J. 2019. Soil Bioavailability of Cadmium, Lead, and Zinc in the Areas of $\mathrm{Zn}-\mathrm{Pb}$ Ore Mining and Processing (Bukowno, Olkusz). Journal of Ecological Engineering, vol.: 20 Issue: 1, pages: 84-92, doi: $10.12911 / 22998993 / 93794$

15. Kicińska-Świderska A. 1999. Metale ciężkie w glebach i w roślinach na wybranych obszarach oddziaływania przemysłu hutniczego. Praca doktorska, AGH, Kraków. s. 235.

16. Kicki J. 1997. Technologia eksploatacji złóż rud cynku i ołowiu. Rozdział 2, Monografia Surowce mineralne Polski (Ney R. red.), Surowce metaliczne cynk ołów (Kicki J. red.). Wydawnictwo CPPGSMiE PAN, Kraków.

17. Kosa B., Kicińska A., 2016. Coal from the waste disposal site of the Siersza mine (Trzebinia, Poland) and its properties as a possible alternative fuel. E3S Web of Conferences, Volume: $10 \mathrm{Ar}$ ticle Number: UNSP 00039, DOI: 10.1051/e3sconf/20161000039

18. Larcher W. 2003. Physiological plant ecology. Berlin, Springer

19. Liu J., Wang J., Chen Y., Xie X., Qi J., Lippold H., Luo D., Wang C., Su L., He L., Wu Q. 2016. Thallium transformation and partitioning during $\mathrm{Pb}-\mathrm{Zn}$ smelting and environmental implications, Environmental Pollution, 212: 77-89, doi.org/10/1016/j. envpol.2016.01.046

20. Maskall J., Whitehead K., Gee C., Thornton I. 1996. Long-term migration of metals at historical smelting sites. Applied Geochemistry, 11: 43-51.

21. Newman M.C., Jagoe C.H. 1996. Ecotoxicology: A Hierarchical Treatment. CRC Press, Taylor \& Francis Group.

22. Nowińska K. 2003. Dystrybucja niektórych pierwiastków śladowych na drodze od koncentratu rudy $\mathrm{Zn}-\mathrm{Pb}$ do odpadów na przykładzie huty cynku „Miasteczko Śląskie”. Praca doktorska, Politechnika Śląska, Gliwice, 3. 153.

23. Pulford I.D., Watson C. 2003. Phytoremediation of heavy metal-contaminated land by trees-a review. Environment International, 29:529- 540, doi:10.1016/S0160-4120(02)00152-6

24. Regulation of the Minister of the Environment 2016 on the method of conducting the assessment of surface pollution (Dz. U. 2016, poz. 1395)

25. Szarek-Łukaszewska G. 2009. Vegetation of reclaimed and spontaneously vegetated $\mathrm{Zn}-\mathrm{Pb}$ mine wastes in southern Poland. Polish Journal of Environmental Studies, 18, 4, 717-733.

26. Turan D., Kocahakimoglu C., Kavcar P., Gaygisız H., Atatanir L., Turgut C., Sofuoglu S.C. 2011. The use of olive tree (Olea europaea L.) leaves as a bioindicator for environmental pollution in the Province of Aydın, Turkey. Environmental Science and Pollution Research 18: 355-364, doi:10.1007/ s11356-010-0378-Z

27. Tyler G., Olsson T. 2001. Plant uptake of major and minor mineral elements as influenced by soil acidity and liming. Plant and Soil 230: 307-321. 